\title{
P-62
}

\section{Chemical Constituents and Cytotoxicity Activity of Phaleria Macrocarpa (SCHEFF) Boerl. Fruits on MCF-7 Cell Line}

\author{
Siti Nur Atiqah Md Othman ${ }^{1}$, Siti Pauliena Mohd Bohari ${ }^{2, *}$ and Norazah Basar ${ }^{1}$ \\ ${ }^{1}$ Department of Chemistry, Faculty of Science, Universiti Teknologi Malaysia, 81310 Skudai, Johor; ${ }^{2}$ Department of \\ Industrial Biotechnology, Faculty o Bioscience and Medical Engineering, Universiti Teknologi Malaysia, 81310 Skudai, \\ Johor; E-mail: Pauliena@Fbb.Utm.My
}

Successive extraction method of dried fruits of Phaleria macrocarpa had afforded chloroform, ethyl acetate and ethanol crude extracts. Two benzophenone derivatives which are 2,4,4'-trihydroxy-6-methoxybenzophenone (1) and 4,4'-dihydroxy-2methoxy- benzophenone-6-O- $\beta$-D-glucopyranoside (2) were isolated from the ethyl acetate crude extract. The structures of these compounds were elucidated by spectroscopic techniques using Infrared spectroscopy (IR), 1D (1H, 13C, DEPT), 2D (COSY, HMQC, HMBC) NMR spectroscopy and mass spectrometry. The cytotoxic activity of the crude extracts and benzophenones were tested against human breast carcinoma cell line (MCF-7). MTT assay method was applied to measure the viability of cells at eight different concentrations. The ethyl acetate crude extract was showed higher cytotoxicity activity with IC50 value $126.67 \mu \mathrm{g} / \mathrm{mL}$ compare with ethanol extract $(218.33 \mu \mathrm{g} / \mathrm{mL})$ and chloroform extract $(278.33 \mu \mathrm{g} / \mathrm{mL})$. Meanwhile, benzophenone (1) and benzophenone (2) were exhibited potent cytotoxic properties with IC50 values $141.00 \mu \mathrm{g} / \mathrm{mL}$ and 166.00 $\mu \mathrm{g} / \mathrm{mL}$, respectively.

Keywords: Phaleria macrocarpa, benzophenone derivatives, cytotoxic activity, MCF-7. 